> Gi respons på artikler gjennom artiklenes kommentarfelt på tidsskriftet.no.

Innleggene publiseres fortløpende på Tidsskriftets nettside og et utvalg

av innleggene publiseres også i papirutgaven i spalten «Brev til redaktøren».

Redaksjonen forbeholder seg retten til å foreta redaksjonelle endringer.

Forfattere av vitenskapelige artikler har tilsvarsrett, jf. Vancouver-gruppens regler.

\section{Re: Utredning ved mistenkt kronisk utmattelsessyndrom}

\section{O.B. Tysnes og medarbeidere svarer:}

Aksel Tveråmo \& Ine Baug Johnsen kommenterer i Tidsskriftet nr. 6/2016 (1) vår artikkel Utredning ved mistenkt kronisk utmattelsessyndrom/Myalgisk encefalopati (2). Vår konklusjon er at nær halvparten av pasienter som henvises til en nevrologisk enhet til utredning for kronisk tretthet har underliggende psykososial problemstilling. Tveråmo og Johnsen viser til Helsedirektoratets veileder som uttaler at det ikke foreligger behov for uttalelse fra psykiater i forbindelse med utredning av tilstander med kronisk tretthet. Det trekkes ut fra vårt arbeid at vi ønsker at pasientene skal være «psykiatrisk» utredet i primærhelsetjenesten.

Arbeidet fra Haukeland universitetssykehus viser at det kommer svært lite ut av omfattende somatisk utredning av disse pasientene. En nærliggende konklusjon må være at pasienter med symptomer i form av kronisk utmattelse er svært godt somatisk utredet i primærhelsetjenesten. Henvisning til spesialisthelsetjenesten, der ventetiden kan være opp mot 12 måneder, forsinker i vesentlig grad den diagnostiske vurderingen, noe som etter vår vurdering setter pasientene $i$ en vanskelig situasjon. I tillegg risikerer den somatiske utredningen å føre til ytterligere helseplager i form av hodepine etter gjennomført spinalpunksjon. Det er vår vurdering etter aktuelle gjennomgang at psykososiale faktorer er en vesentlig risikofaktor ved opptreden av symptomet kronisk utmattelse. Dette er i for liten grad fokusert eller vektlagt som mulig årsak til symptomene før pasientene henvises til utredning i den nevrologiske spesialisthelsetjenesten.

Tveråmo \& Johnsen erkjenner at kroniske utmattelsestilstander oppstår «i et samspill mellom kropp og sjel». De foreslår tverrfaglig tilnærming gjennom et team bestående av forskjellige spesialister.

Som det fremgår i vårt arbeid er kronisk utmattelse et svært vanlig symptom. Ventetiden for utredning er uhensiktsmessig lang. Det er vår vurdering at utredningen i primærhelsetjenesten kan dra nytte av vårt arbeid og argumentere for at det er svært lav sannsynlighet for at man i primærhelsetjenesten har oversett somatisk årsak til symptomene. Pasientene vil da ha muligheter til selv å vurdere hvorfor de har symptomer i form av en kronisk utmattelse. Dersom de ønsker videre utredning innen psykisk helsevern kan dette naturligvis være aktuelt, men fra vårt ståsted mener vi fastlegen har mulighet for å tilnærme seg denne problemstillingen med bakgrunn i arbeidet som ble utført ved Haukeland universitetssykehus. Med kunnskap om pasientens bakgrunn - både somatisk og psykososialt - vil fastlegen være i en god posisjon til å vurdere årsaksforklaringer til pasientens symptombilde. En forsinkende tverrfaglig utredning av tilstanden vil etter vårt syn vil etter vårt syn øke risikoen for at pasienter med kronisk utmattelse vil oppleve et forlenget og ytterligere forverret sykdomsforløp.

\section{Ole-Bjørn Tysnes \\ obty@haukeland.no \\ Halvor Næss}

Jone Owe

Ole-Bjørn Tysnes (f. 1956) er spesialist i nevrologi, professor og avdelingssjef.

Ingen oppgitte interessekonflikter.
Halvor Næss (f. 1957) er spesialist i nevrologi, professor og overlege. Ingen oppgitte interessekonflikter.

Jone Furlund Owe (f. 1975) er spesialist i nevrologi med phd. Han er overlege og har hatt ansvaret for studien på utredning av kronisk utmattelsessyndrom/ myalgisk encefalopati.

Ingen oppgitte interessekonflikter.

Litteratur

1. Tveråmo A, Johnsen IB. Re: Utredning ved mistenkt kronisk utmattelsessyndrom/myalgisk encefalopati. Tidsskr Nor Legeforen 2016; 136: 509

2. Owe JF, Næss H, Gjerde IO et al. Utredning ved mistenkt kronisk utmattelses syndrom/myalgisk encefalopati. Tidsskr Nor Legeforen 2016; 136: 227-32.

\section{Re: Bør man kunne tilby keisersnitt ved trisomi 13 eller 18 ?}

Takk til Fredheim og medarbeidere for en ryddig gjennomgang av etiske betraktninger omkring keisersnittsforløsning ved kjent trisomi 13 og 18 hos barnet i Tidsskriftet nr. 7/2016 (1). På et punkt stiller jeg meg imidlertid kritisk til vurderingen av sakens faktagrunnlag, når forfatterne skriver at «Avgjørende for Ruud Hansen og Haugen er at keisersnitt innebærer betydelig økning i relativ risiko og (...)». Det presiseres ikke «risiko for hva», men uansett er relativ risiko ikke den relevante parameteren. Relativ risiko er egnet til å påvise assosiasjoner mellom fenomener og kan således belyse årsakssammenhenger, men for enkeltpasienter er det økning/reduksjon i absolutt risiko som er av interesse. Og etiske valg innebærer valg for, og sammen med, enkeltpasienter. Relativ risiko kan brukes til å beregne absolutt risiko, men kun hvis man også tar hensyn til basisfrekvensen av den aktuelle tilstanden.

For å konkretisere dette i den aktuelle saken, kan vi låne tall fra en artikkel Fredheim og medarbeidere nevner blant sine kilder (2). Der fremkommer det for eksempel at forekomsten av placenta previa er 2,2 per $1000 \mathrm{i}$ andre svangerskap dersom første svangerskap ble vaginalt forløst, og 3,3 per 1000 dersom første svangerskap ble forløst med keisersnitt. Dette gir statistisk signifikant økt odds ratio på 1,4 (kan tolkes som relativ risiko fordi utfallet er sjeldent), men den absolutte risikoøkningen er kun på $0,1 \%$, altså neglisjerbart for den enkelte kvinne når hun skal vurdere alternative forløsningsmetoder.

Uterinruptur er komplikasjonen med høyest odds ratio (på 37) for svangerskap som etterfølger keisersnitt. Men fordi uterinruptur er sjeldent gir dette kun knapt 0,2\% økning i absolutt risiko: For gravide kvinner som tidligere har hatt keisersnitt er sannsynligheten for å unngå uterinruptur faktisk 99,8\%, mens tilsvarende tall er for gravide som tidligere har hatt vaginalforløsning er 99,994\%. Jeg tviler på om dette er en opplysning som vil skremme kvinner fra å be om keisersnitt, hvis de ellers har gode grunner for å ønske det.

Dersom man argumenterer fra et befolkningsperspektiv betyr dette at man kan forvente én ekstra uterinruptur for hvert 500. keisersnitt som blir gjort. Men i dette perspektivet er det vesentlige å redusere unødvendige keisersnitt generelt, og ikke knyttet til barnets diagnose eller prognose. Fordi trisomi 13 og 18 er såpass sjeldent, vil en restriktiv praksis når det keisersnitt for disse barna utgjøre en ekstremt liten forskjell for folkehelsen og helseøkonomien i Norge, slik at dette heller ikke blir et tungtveiende argument. 
Optimalt skulle man vurdert samlet økning i absolutt risiko for alle uønskede hendelser.

\section{Kristoffer Brodwall \\ kristoffer.brodwall@uib.no}

Kristoffer Brodwall (f. 1979) er lege/ph.d.-stipendiat ved Institutt for global helse og samfunnsmedisin, Universitetet i Bergen.

Ingen oppgitte interessekonflikter.

\section{Litteratur}

1. Fredheim OMS, Hansen TWR, Haugen G et al. Bør man kunne tilby keisersnitt ved trisomi 13 og 18? Tidsskr Nor Legeforen 2016; 136: 630-2.

2. Daltveit AK, Tollånes MC, Pihlstrøm $\mathrm{H}$ et al. Cesarean delivery and subsequent pregnancies. Obstet Gynecol 2008; 111: 1327-34.

\section{Re: Bør man kunne tilby keisersnitt ved trisomi 13 og 18 ?}

Kan etisk problemdefinisjon tilsidesette pasientrettigheter? Fredheim og medforfattere har i Tidsskriftet nr. 7/2016 på trykk en artikkel som reiser flere problemstillinger (1). Juridisk sett har pasienter rett til å medvirke ved behandlingsvalg. Dette gjelder også gravide pasienter. En vanlig fortolkning har vært at keisersnitt er en relativt dyr og risikofylt affære som ikke er en rettighet for kvinnen. Gravide som får påvist trisomi hos fosteret, kan oppleve at behandlingsvalg (ved fortsettelse av svangerskapet) som for foster uten trisomi er selvsagte, blir nektet i trisomisvangerskap. Er et kort liv for barnet verd et keisersnitt(risiko)? Og er det rett å redde et barn med trisomi? Begrunnelsen til den gravide vil være at hun ønsker å holde liv i sitt foster/den nyfødte og for eksempel oppleve en kort nyfødtperiode eller at livreddende tiltak i lenger perspektiv kan settes i verk. Jeg synes at før man hamrer løs med filosofisk teori bør man tilkjennegi sitt teoretiske utgangspunkt. Er det utilitarisme (maksimering av velferd for mulig flest mulig) eller pliktetikk? Hvilken vekt skal man legge på religiøse tankesett? Tydeliggjøring av startposisjon savnes i artikkelen. Artikkelen sin modell for refleksjon blir i praksis overordnet kvinnens refleksjoner rundt egen kropp og eget barn. Ved abort er det er det ikke naturlig å bruke etisk medisinsk refleksjonsteori fra fagpersonellet sin side. Derimot, dersom hun ønsker å gjøre det motsatte, nemlig å holde liv i fosteret lengst mulig, blir den autonome handling(kvinners rett til å bestemme over egen kropp) og konsekvensene(fosterets overlevelse) et etisk problem for en del personell i foster - og nyfødtmedisin. Jeg mener at det å definere et etisk problem her, er et direkte angrep på kvinners autonomi i reproduktive spørsmål. Artikkelens konklusjon er ok, mange av elementene kan inngå i prosessen ved å legge grunnlaget for et informert valg, men veien dit er provoserende. Artikkelen er kanskje ment å bygge en bro mellom gammeldags paternalisme og moderne rettighetstenkning. Når kvinner kan velge abort (som jeg antar vi er enige om), bør de også få velge et for fosteret livreddende keisersnitt, uten at noen setter seg til doms over det, utfra et prinsipp om kroppslig autonomi. Fremtidig livskvalitet er en subjektiv størrelse.

\section{Åsta Årøen \\ asta.aroen@venstre.no}

Åsta Årøen (f. 1971) er politiker, jurist og administrasjonsleder. Oppgitte interessekonflikter: Forfatteren har selv opplevd å gå igjennom et svangerskap der avvik ble påvist. Barnet døde av seg selv i uke 28. Svangerskapet var en god tid, selv om det var en tid med gjentatte dårlige møter med norsk helsevesen.

\footnotetext{
Litteratur

1. Fredheim OMS, Hansen TWR, Haugen $G$ et al. Bør man kunne tilby keisersnitt ved trisomi 13 og 18? Tidsskr Nor Legeforen 2016; 136: 630-2.
}

\section{Re: Bør man kunne tilby keisersnitt ved trisomi 13 og 18 ?}

Jeg har gjort meg noen tanker om artikkelen i Tidsskriftet nr. 7/ 2016 (1). Det kan hende fokuset er for sterkt knyttet til diagnose i stedet for barnets tilstand. En utelukkende diagnosebasert vurdering er diskriminerende, $i$ strid med konvensjonen om rettighetene til mennesker med utviklingshemning og i strid med barnekonvensjonen, i det minste fra det tidspunktet barnet er født.

\section{Jens Petter Gitlesen \\ jpg@nfunorge.org}

Jens Petter Gitlesen (f. 1959) er forbundsleder, Norsk Forbund for Utviklingshemmede (NFU).

Oppgitte interessekonflikter: Som forbundsleder i Norsk Forbund for Utviklingshemmede arbeider jeg kontinuerlig for å sikre likeverd, likestilling og mot diskriminering av mennesker med utviklingshemning.

\section{Litteratur}

1. Fredheim OMS, Hansen TWR, Haugen $G$ et al. Bør man kunne tilby keisersnitt ved trisomi 13 og 18? Tidsskr Nor Legeforen 2016; 136: 630-2.

\section{O. Fredheim og medarbeidere svarer:}

Vi er takknemlige for kommentarene til vår artikkel. Det er viktig at personlige erfaringer får komme frem i debatten. Kommentarene viser at den tidligere oppfatningen om prognosen ved trisomi 13/18 som nødvendigvis håpløs («uforenlig med liv»), var feilaktig.

Innlegget fra Gitlesen inviterer til en mye mer omfattende diskusjon enn det er plass til innenfor rammene av et replikkordskifte. Til Årøens kommentar vil vi bemerke: Vi har ikke brukt filosofisk teori, men forsøkt å drøfte det etiske dilemmaet med keisersnitt ved trisomi $13 / 18$ på en praksisnær måte, ved å ta alle berørte parters syn og interesser og involverte verdier med i vurderingen. Et etisk dilemma eller problem kjennetegnes ved usikkerhet eller uenighet om hva som er rett å gjøre, i en valgsituasjon der viktige menneskelige goder og verdier står på spill. Det å definere avveiningen om å tilby keisersnitt eller ikke når fosteret har trisomi 13 eller 18 som et etisk problem, er rett og slett en anerkjennelse av at det finnes ulike syn blant både pasienter og helsepersonell. Som vi viser, gir refleksjonsmodellen plass for de gravides refleksjoner og syn, som momenter som må være tungtveiende i den etiske drøftingen og avveiningen. Men vi viser også at det er andre berørte parter som må høres og andre verdier som må hensyntas. Hvis Årøen mener at den gravides "kroppslige autonomi» er et hensyn som alltid skal veie tyngre enn alle de andre hensynene som vi har vist er moralsk relevante, må hun argumentere nærmere for dette.

\section{Olav Fredheim \\ olav.m.fredheim@ntnu.no \\ Thor Willy Ruud Hansen \\ Guttorm Haugen \\ Morten Magelssen}

Olav Fredheim (f. 1979) er overlege og professor ved Norges teknisknaturvitenskapelige universitet og Akershus universitetssykehus. Ingen oppgitte interessekonflikter.

Thor Willy Ruud Hansen (f.1946) er overlege og professor ved Oslo universitetssykehus og Universitetet i Oslo.

Ingen oppgitte interessekonflikter.

Guttorm Haugen (f. 1953) er overlege og professor ved Oslo universitetssykehus og Universitetet i Oslo.

Ingen oppgitte interessekonflikter.

Morten Magelssen (f. 1978) er lege med ph.d. og forsker ved Universitetet i Oslo.

Ingen oppgitte interessekonflikter. 